\title{
Leguminosae: Florística e Taxonomia de áreas de Cerrado do Maranhão, Nordeste do Brasil
}

\section{Leguminosae: Floristics and Taxonomy of areas of Cerrado of Maranhão, Northeast Brazil}

\author{
Gustavo da Silva Gomes ${ }^{(1)}{ }^{1}$, Guilherme Sousa da Silva ${ }^{\left(D^{2}\right.}{ }^{\text {, Gonçalo Mendes da Conceição (iD }}{ }^{3}$
}

${ }^{1}$ Graduando em Ciências Biológicas Licenciatura, Universidade Estadual do Maranhão, Caxias, Maranhão. E-mail: gustavogomes @ aluno.uema.br; ${ }^{2}$ Mestre em Botânica, Instituto Nacional de Pesquisas da Amazônia, Manaus, Amazonas, Brasil. E-mail: guilhermecx.cx@ hotmail.com; ${ }^{3}$ Doutor em Zootecnia, Docente da Universidade Estadual do Maranhão, Caxias, Maranhão, Brasil. E-mail: doutorgoncalo@ gmail.com.

\section{A R T I G O}

Recebido: $12 / 02 / 2019$

Aprovado: 30/03/2019

Palavras-chave:

Biodiversidade

Mimosa L.

Mata de Galeria

Key words:

Biodiversity

Mimosa L.

Gallery Forest

\section{R E S U M O}

Esta pesquisa contribui para o conhecimento taxonômico de Leguminosae no Cerrado do Maranhão, Nordeste do Brasil. A coleta e a herborização das amostras foram realizadas de acordo com a metodologia usual para a família em estudo. Leguminosae está representada por 50 espécies e 29 gêneros, distribuídas em quatro subfamílias: Papilionoideae (22 spp.), Caesalpinioideae (20 spp.), Cercidoideae (6 spp.) e Detarioideae (2 spp.). Mimosa L. foi o gênero que apresentou a maior riqueza $(8 \mathrm{spp}$.). A forma de vida arbustiva foi a mais representativa (19 ssp.), enquanto que Mata de Galeria foi a fitofisionomia mais diversa (24 spp.). Assim, foi criada a chave de identificação para as subfamílias, descrições gerais e material examinado para cada espécie.

\section{INTRODUÇÃO}

A família Leguminosae Juss. é reconhecida por sua importância econômica e ecológica (YAHARA et al., 2013; SPRENT et al., 2017). Quanto a diversidade de espécies, é a terceira maior família de angiospermas, com 770 gêneros e 19.500 espécies (LPWG, 2017). Recentemente a família foi circunscrita em seis subfamílias com base em estudos moleculares e morfológicos: Papilionoideae (503 gêneros e 14000 espécies), Caesalpinioideae (146 gêneros e 4400 espécies), Detarioideae (84 gêneros e 760 espécies), Dialioideae (17 gêneros e 85 espécies), Cercidoideae (12 gêneros e 335 espécies) e Duparquetioideae (1 gênero e 1 espécie) (LPWG, 2017).

Leguminosae é reconhecida pelo hábito de vida variável, desde ervas, lianas, arbustos e árvores; folhas compostas, filotaxia alterna, presença de pulvino e estípulas, ovário súpero e fruto do tipo legume, com algumas variações nesses caracteres (LEWIS et al., 2005; SOUZA; LORENZI, 2012).
Em relação a sua importância ecológica, é bem conhecida pela eficiente associação com bactérias que fixam nitrogênio (YAHARA et al., 2013). Essa importante adaptação possibilita a colonização de solos desprovidos de nutrientes e garante a colonização de ambientes com forte influência antropogênica (LEWIS, 1987). Em termos econômicos, a família é utilizada na alimentação, forragem, adubação verde, produção de madeira, fitoquímica na extração de taninos, óleos, resinas e na fabricação de vernizes, tintas e medicamentos (LPWG, 2017).

Leguminosae possui distribuição subcosmopolita (LAVIN et al., 2004; SCHMIDT-SILVEIRA; MIOTTO, 2013), e ocorre em todos os domínios fitogeográficos brasileiros (BFG, 2015; DRYFLOR, 2016). Para o Brasil 222 gêneros são registrados para Leguminosae, distribuídos em 2.848 espécies, das quais são 1.539 são endêmicas (BFG, 2015; FLORA DO BRASIL 2020, 2019).

Para o Maranhão, são registrados 2855 espécies de angiospermas (FLORA DO BRASIL 2020, 2019), ocupando

\section{Revista Verde}

ISSN 1981-8203

Pombal, Paraíba, Brasil v. 14, n.2, abr.-jun, p.317-330, 2019

doi: $10.18378 /$ rvads.v14i2.6364 
o $19^{\circ}$ lugar em riqueza de espécies de angiospermas no Brasil, quando comparado as outras federações brasileiras (BFG, 2015), o que indica que o estado pode ser subamostrado, uma vez que apresenta várias lacunas de conhecimento com áreas sem nenhum estudo ou levantamento florístico realizado. Tratando apenas das Leguminosas no estado do Maranhão são registrados 111 gêneros e 408 espécies, e quando se leva em consideração o Cerrado (dominante no Estado) são registrados 94 gêneros e 296 espécies (FLORA DO BRASIL 2020, 2019).

Assim, dentre as pesquisas já realizadas no Cerrado brasileiro, destacam-se Oliveira-Filho; Ratter (1995); Ratter et al. (2003) e Mendonça et al. (2008), onde Leguminosae foi a família mais representativa, e no Cerrado do Maranhão, com ênfase na família destacam-se apenas os trabalhos de Silva (2015); Gomes et al. (2016 e 2017), demonstrando o baixo nível de investimento no conhecimento florístico da família no estado. Desta forma, a pesquisa teve por objetivo descrever o conhecimento taxonômico da família Leguminosae para áreas de Cerrado no estado do Maranhão.

\section{MATERIAL E MÉTODOS}

O Maranhão (latitudes $01^{\circ} 09^{\prime} 11^{\prime \prime}-10^{\circ} 18 ' 22$ 's e longitudes $41^{\circ} 48^{\prime} 00^{\prime}$ ' $\left.45^{\circ} 51^{\prime} 21^{\prime \prime} \mathrm{W}\right)$, pertence a região Nordeste do Brasil, com área aproximada de $331.937 \mathrm{~km}^{2}$ (IMESC, 2008; IBGE, 2014). O Estado é composto por três diferentes domínios fitogeográficos (Cerrado, Caatinga e Amazônia), o que contribui potencialmente para abrigar uma flora altamente rica e abundante (GALINKIN et al., 2004).

O Cerrado é o domínio fitogeográfico predominante em extensão territorial no Maranhão, com 64,1 \% da sua área total (SPINELLI-ARAUJO et al., 2016). A mesorregião Leste maranhense, é atualmente formada por 44 municípios, agrupados em seis microrregiões (LIMA et al., 2016).

Os municípios Coelho Neto, São João do Sóter e Caxias da região Leste do estado (Figura 1), foram selecionados para a realização da pesquisa, por abrangerem fragmentos consideráveis de Cerrado e estrutura vegetacional, com forte diversidade de espécies botânicas (MARANHÃO, 2011).

Figura 1. Município/Área de coleta na região Leste do Estado do Maranhão.

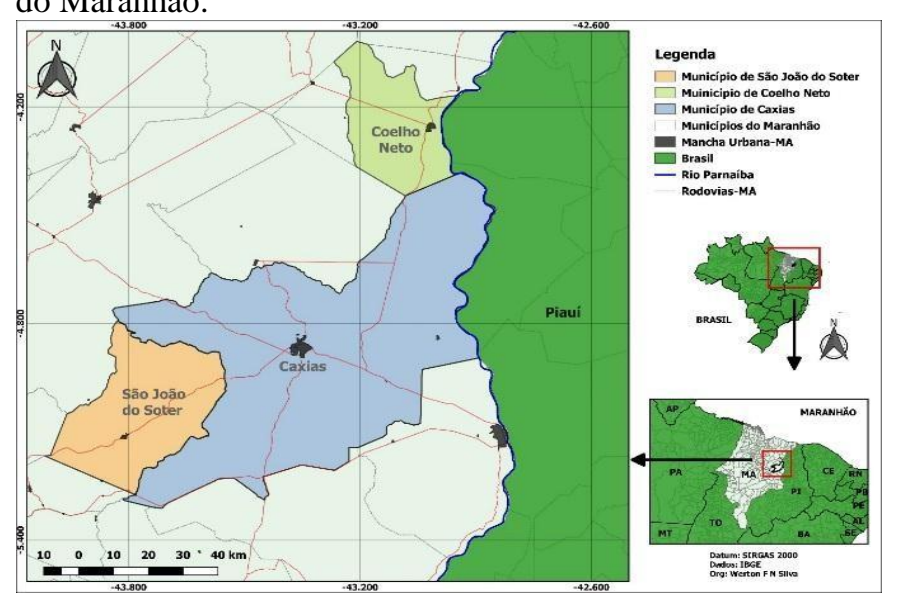

Fonte: IBGE, 2014.

A coleta do material botânico foi realizada mensalmente, no período de agosto de 2017 a maio de 2018.
Durante as incursões ao campo, todos os indivíduos férteis (com flores e/ou frutos), de todas as espécies de Leguminosae encontradas foram coletados. O material coletado foi preparado de acordo com as técnicas usuais de herborização, de acordo com Mori et al. (1989).

Após as coletas, os espécimes foram identificados por meio de comparação com o material tipo, por meio de literatura especializada e amostras certificadas por especialistas, sendo classificadas de acordo com a circunscrição proposta em LPWG (2017). Todas as amostras foram incorporadas ao Herbário Prof. Aluízio Bittencourt (HABIT), do Centro de Estudos Superiores de Caxias (CESC), da Universidade Estadual do Maranhão (UEMA).

A terminologia morfológica para descrição das espécies e elaboração das chaves taxonômicas seguiu Radford et al. (1974) e Barroso et al. (1999). Para categorização do hábito de vida e fitofisionomias de ocorrência das espécies foi utilizado a lista de espécies da Flora do Brasil em construção 2020 e IBGE (2012), respectivamente.

Para a classificação das fitofisionomias de Cerrado encontradas nas áreas estudadas foi utilizado Ribeiro et al. (1983). As informações nomenclaturais e obras originais foram obtidas com o uso de sítios eletrônicos específicos, como The Plant List (2018), Lista de espécies da Flora do Brasil em construção 2020 (2019) e Tropicos.org (2019).

\section{RESULTADOS E DISCUSSÃO}

Leguminosae está representada na área estudada por 50 espécies, distribuídas em 29 gêneros e quatro subfamílias: Papilionoideae (22 spp.), Caesalpinioideae (20 spp.), Cercidoideae (6 spp.) e Detarioideae (2 spp.) (Tabela 1). Mimosa L. foi o gênero que apresentou maior riqueza em número de espécies ( $8 \mathrm{spp}$.). Este gênero compreende cerca de 536 espécies (JORDÃO et al., 2018), distribuídas principalmente na região Neotropical (BARNEBY, 1991; SIMON et al., 2011). Dentre as espécies coletadas, a maior representatividade foi do hábito de vida arbusto (19 spp). Apesar deste modo de vida ter predominado, a família possui hábito bem variado, que compreende, desde ervas até árvores (JUDD, et al., 1999; QUEIROZ, 2009). Estudos prévios realizados com Leguminosae nos mesmos fragmentos de Cerrado estudados, corroboram com os dados aqui apresentados para o hábito de vida da família (SILVA, 2015; GOMES et al. 2016, 2017).

Nas fitofisionomias da vegetação onde as espécies foram coletadas, observou-se que a mais representativa foi Mata de Galeria (24 spp.), seguida por Cerrado sujo (14 spp) e Cerrado limpo (12 spp.). Em relação as fitofisionomias observadas, Leguminosae por possuir uma fácil adaptação, ocorre nos mais diferentes ambientes, e pode contribuir para o desenvolvimento de outros grupos (LEWIS et al., 2005; QUEIROZ, 2009). As fitofisionomias apresentadas são similares as encontradas em trabalhos anteriores para o Cerrado do Maranhão, por Silva (2015) e Gomes et al. (2017) que realizaram pesquisas em áreas de Cerrado no Leste maranhense. Assim, é evidente a distribuição de espécies no Maranhão, visto que o domínio fitogeográfico dominante possui variadas fitofisionomias (BFG, 2015). 
Tabela 1. Lista de espécies de Leguminosae para o Cerrado do Maranhão/Brasil, com suas respectivas subfamílias.

\begin{tabular}{|c|c|c|}
\hline & Espécies & Subfamília \\
\hline 1. & Caesalpinia pulcherrima (L.) Sw. & \multirow{20}{*}{ Caesalpinioideae } \\
\hline 2. & Chamaecrista desvauxii (Collad.) Killip & \\
\hline 3. & Chamaecrista nictitans (L.) Moench & \\
\hline 4. & Inga edulis Mart. & \\
\hline 5. & Inga leiocalycina Benth. & \\
\hline 6. & Libidibia ferrea (Mart. Ex Tul.) L.P Queiroz & \\
\hline 7. & Mimosa acutistipula (Mart.) Benth. & \\
\hline 8. & Mimosa caesalpiniifolia Benth. & \\
\hline 9. & Mimosa candollei R. Grether & \\
\hline 10. & Mimosa invisa Mart. ex Colla & \\
\hline 11. & Mimosa modesta (Harms) Barneby & \\
\hline 12. & Mimosa pigra $\mathrm{L}$. & \\
\hline 13. & Mimosa sensitiva $\mathrm{L}$. & \\
\hline 14. & Mimosa xanthocentra Mart. & \\
\hline 15. & Parkia platycephalla Benth. & \\
\hline 16. & Plathymenia reticulata Benth. & \\
\hline 17. & Senegalia polyphylla (DC) Briton & \\
\hline 18. & Senna obtusifolia (L.) H.S. Irwin \& Barneby & \\
\hline 19. & Senna reticulata (Willd.) H.S. Irwin \& Barneby & \\
\hline 20. & Senna velutina (Vogel) H.S. Irwin \& Barneby & \\
\hline 21. & Bauhinia cupulata Benth. & \multirow{6}{*}{ Cercidoideae } \\
\hline 22. & Bauhinia dubia G. Don. & \\
\hline 23. & Bauhinia forficata Link & \\
\hline 24. & Bauhinia ungulata $\mathrm{L}$. & \\
\hline 25. & Schnella flexuosa (Moric.) Walp. & \\
\hline 26. & Schnella glabra (Jacq.) Dugand & \\
\hline 27. & Tamarindus indica $\mathrm{L}$. & \multirow{2}{*}{ Detarioideae } \\
\hline 28. & Hymenaea stigonocarpa Mart. Ex Hayne & \\
\hline 29. & Abrus fruticulosus Wight \& Arn. & \multirow{22}{*}{ Papilionoideae } \\
\hline 30. & Aeschynomene brasilianum (Poir.) DC. & \\
\hline 31. & Aeschynomene fluminensis Vell. & \\
\hline 32. & Aeschynomene histrix Poir. & \\
\hline 33. & Aeschynomene martii Benth. & \\
\hline 34. & Aeschynomene rudis Benth. & \\
\hline 35. & Andira vermifuga (Mart.) Benth. & \\
\hline 36. & Centrosema brasilianum (L.) Benth. & \\
\hline 37. & Clitoria falcata Lam. & \\
\hline 38. & Cratylia argentea (Desv.) Kuntze & \\
\hline 39. & Crotalaria retusa $\mathrm{L}$. & \\
\hline 40. & Desmodium barbatum (L.) Benth. & \\
\hline 41. & Desmodium incanum (Sw.) DC. & \\
\hline 42. & Dioclea bicolor Benth. & \\
\hline 43. & Macroptilium lathyroides (L.) Urb. & \\
\hline 44. & Periandra heterophyla Benth. & \\
\hline 45. & Phaseolus vulgaris L. & \\
\hline 46. & Pterodon emarginatus Vogel. & \\
\hline 47. & Stylosanthes acuminata M.B. Ferreira \& Sousa Costa & \\
\hline 48. & Stylosanthes capitata Vogel. & \\
\hline 49. & Vigna unguiculata (L.) Walp. & \\
\hline 50. & Zornia leptophylla (Benth.) Pittier & \\
\hline
\end{tabular}

\section{Chave para as subfamílias de Leguminosae para Cerrado do Maranhão}

1. Flores papilionáceas, semente com valva hilar complexa, pleurograma ausente, radícula embrionária curvada.................................................................................................................................... Papilionoideae

1. Flores não papilionáceas, semente sem valva hilar complexa, com ou sem pleurograma, radícula embrionária reta.......

2. Semente comumente com um pleurograma aberto ou fechado de cada lado......................... .Caesalpinioideae

2. Semente sem pleurograma aberto ou fechado em ambos os lados ..3 
3. Inflorescência em forma de racemo ou pseudorracemo, hilo da semente circular ou em forma

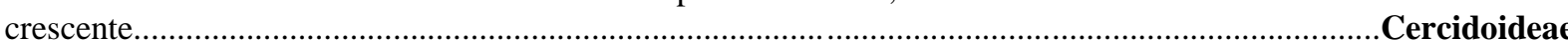

3. Inflorescência em forma de racemo ou panícula, hilo da semente raramente circular com forma não crescente.

Detarioideae

\section{Chave e descrição da subfamília Caesalpinioideae}

1.Folhas sempre bipinadas; flores frequentemente actinomorfas, em espigas, glomérulos ou umbelas, com estames concrescidos em tubo

2. Árvore > $10 \mathrm{~m}$ altura, formação de ritidoma no caule; glomérulos grandes $>5 \mathrm{~cm}$, com estames avermelhados

1. Parkia platycephala

2'. Árvore, arbustos, subarbustos ou ervas $<10 \mathrm{~m}$ altura, caule sem ritidoma; glomérulos pequenos $<5 \mathrm{~cm}$ ou espigas, com estames rosados ou esbranquiçados

3. Nectário extrafloral sempre presente na base do pulvino ou na raquer

4.Pecíolo alado com nectário côncavo arredondado; folíolos $>10$ cm compr.

4'. Pecíolo não alado, com nectário cupuliforme; folíolos $<10 \mathrm{~cm}$ compr.

2. Inga edulis

. Nectário floral ou extrafloral, às vezes presente no pulvino ou no pecíolo

3. Inga leiocalycina

5. Inflorescência em espigas longas; flores pediceladas

5'. Inflorescência em espigas curtas ou glomérulos; flores sésseis

4. Plathymenia reticulata

6. Nectário extrafloral na base do pulvino, glomérulos congestos.

5. Senegalia polyphylla

6'. Nectário extrafloral ausente, espigas ou glomérulos não congestos

7. Árvore $>3 \mathrm{~m}$ altura; inflorescências em racemos

8. Folíolo oblongo, $<1,5 \quad \mathrm{~cm}$ compr., ápice foliar agudoacuminado........................................................................................6. Mimosa acutistipula

8'. Folíolo ovado, > $1,5 \mathrm{~cm}$ compr., ápice foliar arredondado

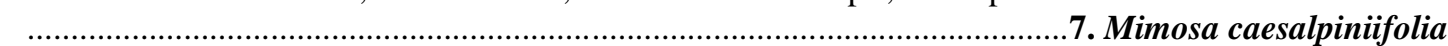

7'. Arbusto ou erva < $3 \mathrm{~m}$ altura; inflorescências sempre em glomérulos ...................................................9

9. Ervas $<1 \mathrm{~m}$ altura, ramos difusos decumbentes ...................................................................... 10

10.Folíolos oblongo-lanceolado, < $1 \mathrm{~cm}$ compr., base do limbo esverdeada

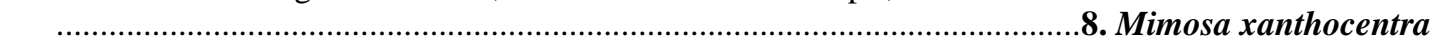

10'. Folíolos obovados, > $1 \mathrm{~cm}$ compr., base do limbo esbranquiçada

9, Subarbustos $>1 \mathrm{~m}$ altura, ramos eretos

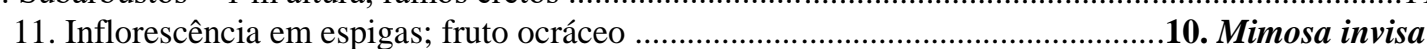

11 '. Inflorescência em glomérulos; fruto craspédio ......................................................................12

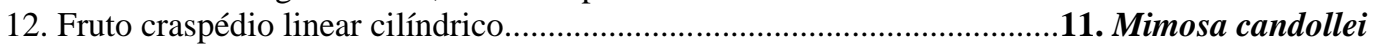

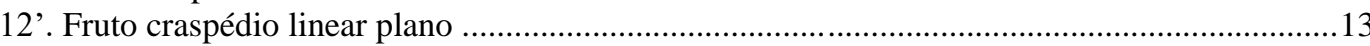

13. Frutos $<3$ cm compr., artículos armados...........................................12. Mimosa sensitiva

13'. Frutos > $3 \mathrm{~cm}$ compr, artículos indumentado de pubescência rufa

13. Mimosa pigra

1'. Folhas bipinadas ou pinadas, flores sempre zigomorfas, em racemos ou panículas nunca glomérulo, com estames livres

14. Flor avermelhada com pétalas $>3 \mathrm{~cm}$ compr.

14. Caesalpinia pulcherrima

14'. Flor amarelada com pétalas $<3 \mathrm{~cm}$ compr.

15.Folhas bipinadas; estandarte vistoso com pigmentos avermelhados; fruto pubescente

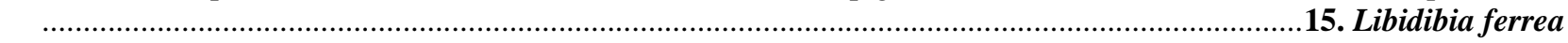

15'. Folhas pinadas; estandarte discreto totalmente amarelado; frutos glabros a pouco pubescentes

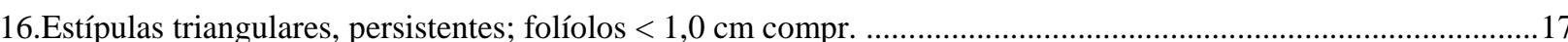

17. Folhas pinadas, folíolo oblongo; estípulas triangulares...

16. Chamaecrista nictitans

17'. Folhas tetrafolioladas, folíolo obovado; estípulas obovais.

17. Chamaecrista desvauxii

16'. Estípulas lineares ou falciformes, caducas; folíolos $>1,0 \mathrm{~cm}$ compr. ...18

18. Ervas a subarbustos $<2 \mathrm{~m}$ altura, folíolos obtusos $<5 \mathrm{~cm}$ compr., fruto legume tipo câmara...........................................................................................................................18. Senna obtusifolia

18'. Arbustos a árvores $>2 \mathrm{~m}$ altura, folíolos oblongos ou obovados $>5 \mathrm{~cm}$ compr., fruto legume plano

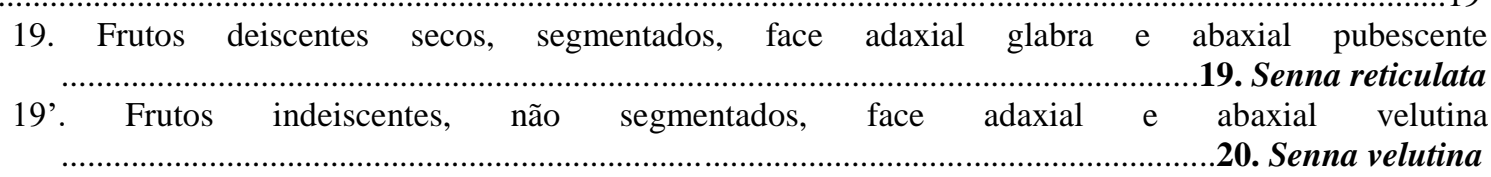


1. $\quad$ Parkia platycephala Benth. J. Bot. (Hooker) 4 (30): 329, 1841.

Descrição: Árvore de $15 \mathrm{~m}$ de altura com caule lenhoso formando ritidoma, crescimento simpodial de copa alta com ramos acinzentados, estípulas ausentes. Folhas bipinadas, folhas longas com 19,5cm apresentando pulvino com 35-50 pares de folíolos, alterna espiralada, folíolos lanceolados diminutos, com 0,6 cm de compr. e 0,2 cm de larg., pecíolo com $7 \mathrm{~cm}$, margem inteira, base arredondada, ápice foliar agudo, nervura peninérvea, inflorescência cimosa. Flores actinomorfas, em forma de glomérulos com ca. $6 \mathrm{~cm}$ de compr., estames congrenescido em forma de tubo avermelhados. Fruto seco tipo legume, com ca. de $10 \mathrm{~cm}$ de compr. e 2,5 cm de larg. Material Examinado: BRASIL. MARANHÃO: Caxias, APA (Inhamum), 21/V/2018, G. S. GOMES; G. M. CONCEIÇÃO, 65 (HABIT).

2. Inga edulis Mart. Flora 20(2, Beibl.): 113-114, 1837

Descrição: Árvore de $7 \mathrm{~m}$ de altura, caule lenhoso sem ritidoma, crescimento simpodial de ramificação baixa, estípulas tomentosas, setosas. Pecíolos cilíndricos de 0,2 x 0,2 cm., com raques foliares aladas de 4,6 cm compr. com nectários situados na base do pulvínulos de $0,1 \times 0,1 \mathrm{~cm}$, alargado, côncavo, sésseis com forma circular. Folhas bipinadas com 3-8 pares de folíolos, peciólulo com 0,4 x 0,2 cm., lâmina com 13,5 x $8 \mathrm{~cm}$, margem lisa, ápice agudo, nervura peninérvea. Flores actinomorfas, em glomérulo com 4,0 cm de compr., estames congrenescido em forma de tubo esbranquiçados. Frutos ausentes. Material Examinado: BRASIL. MARANHÃO: São João do Sóter, APP, 22/IV/2018, G. S. GOMES; G. M. CONCEIÇÃO, 34, 35, 82 (HABIT).

3. Inga leiocalycina Benth. London Journal of Botany 4: 598. (London J. Bot.), 1845.

Descrição: Arvore de $5 \mathrm{~m}$ de altura, caule sem ritidomas, forma dos ramos cilíndrico indumento pubescente; lenticelas presentes. Folhas bipinadas, com lâmina de 3,0 x 2,5 cm, com estípulas persistentes de 0,3 x 0,3 cm, lanceolada, pecíolo da folha cilíndrico não alado; raque foliar cilíndrico, com nectários com 0,01 x $0,01 \mathrm{~cm}$, séssil, cupuliforme, margem inteira, ápice agudo, nervura peninérvea. Flor actinomorfa em forma de glomérulo com 3,5 cm de compr., estames congrenescido em forma de tubo esbranquiçados. Fruto linear, indumento do fruto glabro. Material Examinado: BRASIL. MARANHÃO: Caxias, APA (Inhamum), 21/V/2018, G. S. GOMES; G. M. CONCEIÇÃO, 57 (HABIT).

4. $\quad$ Plathymenia reticulata Benth. J. Bot. (Hooker) 4 (30): 334, 1841.

Descrição: Árvore de $4 \mathrm{~m}$ de altura com caule lenhoso em ritidoma, crescimento simpodial, forma embira, estípulas ausentes, nectário ausente. Folhas bipinadas com 20-30 pares de folíolos, $c a$. de $14 \mathrm{~cm}$ de compr., com pulvino, dística, folíolo oblongo, com 1,2 x 0,6 cm., pecíolo com 3,0 cm, margem inteira, ápice foliar emarginado, nervura peninérvea. Inflorescência racemosa em forma de espigas, com aproximadamente $6 \times 0,3 \mathrm{~cm}$., racemos únicos, congestos. Flores actinomorfas, estames congrenescidos em forma de tubo esbranquiçados, pediceladas. Fruto ausente. Material Examinado: BRASIL. MARANHÃO: São João do Sóter, APP, 22/IV/2018, G. S. GOMES; G. M. CONCEIÇÃO, 90 (HABIT).

\section{5. $\quad$ Seneghalia polyphylla (DC.) Britton Annals of the New York Academy of Sciences 35 (3): 142.1936.}

Descrição: Arvore de $4 \mathrm{~m}$ de altura, tronco cilíndrico, caule liso sem ritidomas de coloração escura com ramos glabrascentes, estípulas lanceoladas com 0,1 x 0,1 cm. Folhas bipinadas, pecíolo longo, folíolos com 0,9 x 0,2 cm., oblongos, ápice mucronado, base assimétrica, margem inteira, membranáceo, com nectário na base do pulvino, alterna espiralada. Flores séssil, actinomorfas em glomérulos, com 3,0 cm de compr., com estames congrenescidos em forma de tubo esbranquiçados, congestos. Fruto ausente. Material Examinado: BRASIL. MARANHÃO: Coelho Neto, Povoado Araim, São João do Sóter, APP, 22/IV/2018, G. S. GOMES; G. M. CONCEIÇÃO 15, 25, 95 (HABIT).

\section{Mimosa acutistipula (Mart.) Benth. J. Bot. (Hooker) 4 (31): 391, 1841.}

Descrição: Árvore de $3,5 \mathrm{~m}$ de altura com caule lenhoso sem ritidoma, crescimento simpodial, estipulas do tipo foice, alaranjadas com 0,8 x 0,3cm. Folhas compostas de 3-10 pares de pinas, com 20-35 pares de folíolos, alterna espiralada, folíolo oblongo, com 1,3 x 0,3 cm., pecíolo com 4,5cm de compr., com pares de acúleos na base do pecíolo, margem inteira com ápice foliar agudo a acuminado, nervura paralelinérvea, folíolos pilosos. Flores em inflorescência racemosa com vários racemos produzidos, estames com filetes brancos. Fruto ausente. Material Examinado: BRASIL. MARANHÃO: Coelho Neto, Povoado Araim, 8/X/17, G. S. GOMES; G. M. CONCEIÇÃO 26 (HABIT).

7. Mimosa caesalpiniifolia Benth. (J. Bot. (Hooker) 4 (31): 392, 1841.

Descrição: Árvore de com $3,5 \mathrm{~m}$ de altura, com caule lenhoso, crescimento simpodial ramificado, prostrado, ramos acinzentados a enegrecidos com formação de embira, acúleos em foram de foice presentes com $0,8 \times 0,2 \mathrm{~cm}$. Folhas bipinadas, com 6-12 pares de pinas, alterna, folíolo ovado, com 2,6 x 1,6 cm, pecíolo com 0,2 cm de compr., margem inteira, ápice foliar arredondado, nervura peninérvea. Inflorescência racemosa em forma de espiga, flores do tipo glomérulos, estames de coloração branca, flores sésseis. Fruto legume seco, com 5 x $3 \mathrm{~cm}$ de compr. Material Examinado: BRASIL. MARANHÃO: Caxias, APA (Inhamum), 21/V/2018, G. S. GOMES; G. M. CONCEIÇÃO, 60, 83, 84 (HABIT).

8. $\quad$ Mimosa xanthocentra Mart. Flora 21 (2, Biebl.): 50, 1838.

Descrição: Erva de $60 \mathrm{~cm}$ de altura, ramos difusos decumbentes, caule herbáceo, crescimento simpodial prostrado, ramos inermes, cilíndricos, acúleos de 0,2 x 0,2 cm, no caule; estípulas com 0,3 x 0,2 cm., triangulares. Folhas bipinadas, com 10-15 pares de folíolos, pecíolos $0,2 \mathrm{~cm}$ de compr; folíolos $0,7 \mathrm{x} 0,4 \mathrm{~cm}$., oblongo-lanceolados, limbo totalmente verde. Inflorescência em espigas curtas, flores tipo glomérulos, sésseis, com estames rosas. Fruto legume seco com indumento, 
indeiscente, com 9 x 0,3 cm. Material Examinado: BRASIL. MARANHÃO: Coelho Neto, Povoado Araim, 8/X/17, G. S. GOMES; G. M. CONCEIÇÃO 41 (HABIT).

9. $\quad$ Mimosa modesta var. ursinoides (Harms) Barneby Mem. Bot de Nova York. Gard. 65: 767, 1991.

Descrição: Erva de $30 \mathrm{~cm}$, ramo lignoso difusos decumbentes, cilíndrico, híspido, armado, acúleo persistente. Estípula com 0,4 x $0,4 \mathrm{~cm}$, lanceolada. Folhas bipinadas alternas, com $2 \times 1,1 \mathrm{~cm}$, oblongo, 5 pares de foliólulos, ovado-oblongo, ápice obtuso, margem ciliada, base de coloração branca e resto do limbo verde, face adaxial e abaxial glabras, nervação actinódroma. Inflorescência racemosa curta, flores em glomérulos não congestos, séssil, actinomorfa, cálice inconspícuo, corola tubulosa, pétala rosa. Fruto craspédio, plano, oblongo, armado, 3-5 segmentos de fruto, com valvas armadas. Material Examinado: BRASIL. MARANHÃO: Caxias, APA (Inhamum), 21/V/2018, G. S. GOMES; G. M. CONCEIÇÃO, 61, 62, 63 (HABIT).

10. Mimosa invisa Mart. ex Colla, Herbarium Pedemontanum 2: 255. 1834.

Descrição: Subarbusto de 1,5 m de altura, crescimento simpodial, estípulas com 0,5 x 0,2 cm., linear, ramos cilíndricos. Folhas bipinadas 7-8 pares de folíolos, com aproximadamente 6 x 4,6 cm., alterna espiralada, foliólulos oblongos, ápice mucronado, margem inteira. Inflorescência racemosa em espigas flores sésseis com estames brancos. Fruto ocráceo, não aculeado. Material Examinado: BRASIL. MARANHÃO: São João do Sóter, APP, 22/IV/2018, G. S. GOMES; G. M. CONCEIÇÃO, 85 (HABIT).

\section{Mimosa candollei R. Grether, Novon 10(1): 34. 2000. L.}

Descrição: Subarbusto de $1 \mathrm{~m}$ de altura, decumbente, sem ritidoma, ramo tetrangulado, glabro, estípulas $0,15 \times 0,05 \mathrm{~cm}$., triangulares, caduca. Folhas bipinadas, foliólulos oblongos com 0,6 x 0,1 cm de larg., raque foliar 4,4 x 0,3 cm de larg., alterna, dística, ápice redondo, margem inteira, base redonda, face adaxial e abaxial glabro. Inflorescência axilar, glomérulo com estames numerosos curtos, rosas. Botão oblongo, flor séssil, cálice e corola campanulada, estames rosas, ovário séssil. Frutos do tipo craspédio com $9,8 \times 0,3 \mathrm{~cm}$., linear, reto, cilíndrico, densamente aculeado. Material Examinado: BRASIL. MARANHÃO: Coelho Neto, Povoado Araim, 8/X/17, G. S. GOMES; G. M. CONCEIÇÃO 10 (HABIT).

\section{2. $\quad$ Mimosa sensitiva L. Sp. Pl. 1: 518,1753.}

Descrição: Arbusto de $2 \mathrm{~m}$ de altura, crescimento simpodial ramificado, caule lenhoso, ramos com acúleos rudimentares presentes em todo ramo do arbusto com $0,2 \times 0,1 \mathrm{~cm}$., ramos esverdeados. Folhas tetrafolioladas, alterna, folíolo assimétrico inequiláteros, com 2,6 x 1,0 cm., pecíolo com 3,0 cm de compr., folha 5,6 cm, margem foliar inteira, ápice foliar agudo, nervura actinódroma. Inflorescência racemosa, flor do tipo glomérulo, com estames brancos. Fruto seco do tipo craspédio curto, linear, plano, armado, com aproximadamente 2,0 x 0,3 cm. Material Examinado: BRASIL. MARANHÃO: Coelho Neto, Povoado Araim, 8/X/17, Caxias, APA (Inhamum), 21/V/2018, São João do Sóter, APP, 22/IV/2018, G. S. GOMES; G. M. CONCEIÇÃO 13, 27, 64, 86 (HABIT).

\section{Mimosa pigra L., Centuria I. Plantarum 13-14. 1755.}

Descrição: Arbusto de 2,5 m de altura, ramos cilíndricos, estípulas lanceoladas com $0,3 \times 0,2 \mathrm{~cm}$. Folhas bipinadas, folíolos com $0,4 \times 0,3 \mathrm{~cm}$., oblongo, margem inteira, base assimétrica, face adaxial glabra, face abaxial seríceo, alterna espiralada, pecíolo com $0,5 \mathrm{~cm}$ de compr. Inflorescência axilar, flor em glomérulo pequeno com estames rosas. Fruto, linear do tipo craspédio reto, longo, plano, indumento rufo adnato, com 5,5 x $1 \mathrm{~cm}$. Material Examinado: BRASIL. MARANHÃO: Coelho Neto, Povoado Araim, 8/X/17, G. S. GOMES; G. M. CONCEIÇÃO 20, 21, 22, 23,24 (HABIT).

\section{Caesalpinia pulcherrima (L.) Sw. Observ. Bot. 166, 1791.}

Descrição: Árvore de $4 \mathrm{~m}$, caule lenhoso, crescimento simpodial, presença de acúleos no tronco com $0,4 \times 0,2 \mathrm{~cm}$, estípulas ausentes, folhas bipinadas com 5 pares de pinas, com $30 \mathrm{~cm}$ de comprimento, alterna, folíolos de 7-11 pares, com 6,1 x 3,4 $\mathrm{cm}$., pedúnculo e pedicelo longos. Inflorescência racemosa, flor vermelha com pétalas de $4 \mathrm{~cm}$ de compr. com estames livres, botão obovado, simetria zigomorfa. Fruto seco do tipo legume com 9,3 x 2,5 cm., com valvas lignosas. Material Examinado: BRASIL. MARANHÃO: Coelho Neto, Povoado Araim, 08/X/17, G. S. GOMES; G. M. CONCEIÇÃO 11 (HABIT).

15. Libidibia ferrea (Mart. Ex Tul.) L.P Queiroz Legum. Caatinga 130, 2009.

Descrição: Árvore de $5 \mathrm{~m}$ de altura, caule lenhoso, crescimento simpodial, estípulas ausentes, ramos puberulentos ferrugíneos, folhas bipinadas com aproximadamente 10-15 pares de folíolos, alterna dística, folíolo oblongo, com 3,6 x 1,0 cm. pecíolo com $1,1 \mathrm{~cm}$., folha com $c a .6,5 \mathrm{~cm}$, margem foliar inteira, ápice foliar arredondado, nervura paralelinérvea, folíolos glabros. Flor com aproximadamente $1,0 \times 0,5 \mathrm{~cm}$., flores amarelas, completas, diclamídeas, heteroclamídeas, estandarte vistoso com pigmentos vermelhos, dialistêmones. Fruto indeiscente seco tipo legume, com 7,3 x 2,0 cm de larg., pubescente. Material Examinado: BRASIL. MARANHÃO: Coelho Neto, 8/X/17, Povoado Araim; Caxias, APA (Inhamum), 21/V/2018, G. S. GOMES; G. M. CONCEIÇÃO 9, 58, 59 (HABIT).

16. Chamaecrista nictitans (L.) Moench. Methodus 272, 1794.

Descrição: Erva de $40 \mathrm{~cm}$ de altura, crescimento prostrado, caule herbáceo, ramos de 28 x 16,5 cm. Estípulas triangulares denteadas na base do pecíolo, persistentes, com aproximadamente $0,4 \times 0,1 \mathrm{~cm}$. Folhas, pinadas, folíolos oblongos com ca. 0,1 x $0,1 \mathrm{~cm}$., ráquis cilíndrico com $0,3 \mathrm{~cm}$ de compr., flor zigomorfa, amarela, estandarte discreto, sépalas lanceoladas a ovadas, dorsalmente pubérulas a pilosas, castanhas a esverdeadas, pétalas adaxiais menores, obovadas a espatuladas, pétalas abaxiais 
maiores, uma obovada, curvada sobre o gineceu e os estames. Fruto legume, linear-oblongos, reto a levemente falcados de 3,5 x $0,3 \mathrm{~cm}$. Material Examinado: BRASIL. MARANHÃO: São João do Sóter, APP, 22/IV/2018, G. S. GOMES; G. M. CONCEIÇÃO, 76 (HABIT).

17. Chamaecrista desvauxii H. S. Irwin \& Barneby, New York Bot. Gard. 35: 868. 1982.

Descrição: Arbusto de 1,4 m de altura, crescimento monopodial. Estípulas lineares ou falciformes de 1,0 x 1,0 cm de larg. obovais, persistentes. Folhas tetrafolioladas com 2,0 x 1,1 cm.; nectário peciolar estipitado-cupuliforme, folíolos 0,9 x 0,6 cm., obovais, ápice obtuso a arredondado, base cuneada, margem glabra, cartáceos, nervação paralela, nervuras primárias e secundárias ligeiramente proeminentes em ambas as faces. Flores 3,6 x 2,1 cm., ovais, ápice acuminado, pétalas 1,6 x 1,1 cm, obovais, amarelas, 10 estames de anteras glabras, ovário $0,8 \mathrm{~cm}$ compr. Fruto legume de $3,3 \mathrm{x} 0,5 \mathrm{~cm}$., lineares, sementes retangulares. Material Examinado: BRASIL. MARANHÃO: Caxias, APA (Inhamum), 21/V/2018, G. S. GOMES; G. M. CONCEIÇÃO 82 (HABIT).

18. Senna reticulata (Willd.) H. S. Irwin \& Barneby. Mem. New York Bot. Gard. 35: 458, 1982.

Descrição: Árvore de $6 \mathrm{~m}$ de altura, caule lenhoso, crescimento simpodial, ramos puberulentos enegrecidos. Estipulas de tipo foice, alaranjadas, presentes com 0,8 x 0,3cm., caducas. Folhas compostas de 15-20 pares de pinas, alterna espiralada, folíolo oblongo, com 10 x 4,2 cm., pecíolo com 4,5 cm de compr., com ca. 18cm, margem inteira com ápice foliar emarginado, nervura peninérvea, folíolos pilosos, inflorescência racemosa com vários racemos. Flor zigomorfa, dióica, amarela, completa, diclamídea, heteroclamídea, dialistêmones, estames livres. Fruto legume, plano, deiscente, pubescente com 14 x $2,2 \mathrm{~cm}$. Material Examinado: BRASIL. MARANHÃO: São João do Sóter, APP, 22/IV/2018, G. S. GOMES; G. M. CONCEIÇÃO,98 (HABIT).

\section{Senna obtusifolia (Humb. \& Bonpl.ex Willd.) H.S. Irwin \& Barneby}

Descrição: Arbusto de 1,2 m de altura, crescimento simpodial. Estípulas laterais, lineares com 1,2 x 0,5 cm., caducas, ramos inermes. Folhas imparipinadas com ca. de 3,0 x 2,0 cm., com folíolos obtusos, alterna dística, margem foliar inteira, inflorescência axilar. Flor pedicelada, amarela, zigomorfa. Fruto legume típico, câmara. Material Examinado: BRASIL. MARANHÃO: São João do Sóter, APP, 22/IV/2018, G. S. GOMES; G. M. CONCEIÇÃO 96, 97(HABIT).

20. Senna velutina (Vogel) H.S. Irwin \& Barneby Memoirs of The New York Botanical Garden 35: $232,1982$.

Descrição: Árvore de $5 \mathrm{~m}$ de altura, caule lenhoso, crescimento simpodial, com partes verdes acinzentadas, ramos acinzentados. Estipulas lineares curtas, caducas, folhas compostas, apresenta de 3-5 pares de pinas, peciólulo com até 1,0 x 0,9 $\mathrm{cm}$., folíolos com 7,0 x 3,0 cm, obovados, face superior glabra à puberulenta, nectário com $0,2 \mathrm{~cm}$ de compr. claviforme a estipitada raqueal na base do peciólulo, na primeira juga, pecíolo canaliculado com 0,2 x 0,1 cm. Inflorescência racemosa. Flor amarela pequenas. Fruto seco do tipo legume, linear, segmentado, não segmentados, face adaxial e abaxial velutina com $12 \mathrm{x}$ $1,3 \mathrm{~cm}$. Material Examinado: BRASIL. MARANHÃ̃O: Coelho Neto, Povoado Araim, 8/X/17, G. S. GOMES; G. M. CONCEIÇÃO 12 (HABIT).

Chave e descrição da subfamília Cercidoideae

1. Lianas com ramos grampiformes escandente, limbo foliar sempre partido ..................................................................

2. Ramos flexuosos, folhas partidas em $>1 / 2$ do limbo, ápice agudo, indumento

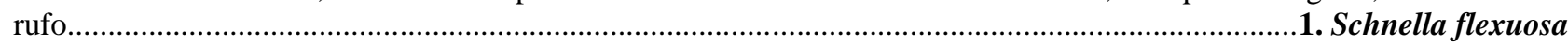

2'. Ramos rígidos, folhas partidas em $<1 / 2$ do limbo, ápice arrendado, indumento glabro.

1'. Arbusto ou subarbustos sem ramos grampiformes, limbo foliar inteiro ou partido

3. Limbo foliar inteiro, face abaxial puberula a glabra, limbo cordado-sagitado. 2. Schnella glabra

3'. Limbo foliar partido, face abaxial indumentado, limbo cordado-truncado 4. Limbo partido em $>1 / 2$ da folha, face abaxial pubescente a tomentoso, lobos ovados- lanceolados

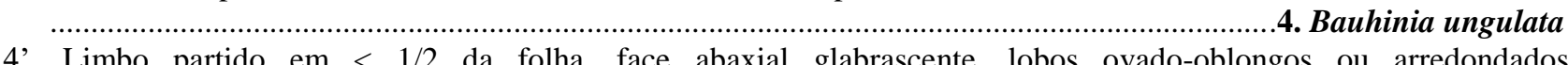
'. Limbo partido em < 1/2 da folha, face abaxial glabrascente, lobos ovado-oblongos ou arredondados

5. Subarbusto, com face do folíolo adaxial e abaxial glabrescente

5. Bauhinia forficata

5'. Arbusto a arvoreta, com face adaxial pubescente e abaxial vilosa 6. Bauhinia cupulata

1. Schnella flexuosa (Moric.) Walp. Repertorium Botanices Systematicae. 5(4): 752, 1846.

Descrição: Liana de $3 \mathrm{~m}$ de altura, caules achatados, ramos flexuosos, estípulas ovado-lanceoladas com $0,5 \mathrm{x} 0,4 \mathrm{~cm}$. Indumento rufo puberulento. Folhas com a lâmina lobada em mais de 1/2, com 3,0 x 3,5 cm., margem inteira, ápice agudo. Inflorescência axilar, racemos densos, espiciformes, com o estilo persistente, um pouco oblíquo ou base de estilo, flores com pétalas brancas, largamente espatuladas, glabro, Fruto elíptico-reniforme, 2,5 x 1,4 cm. Material Examinado: BRASIL. MARANHÃO: São João do Sóter, APP, 22/IV/2018, G. S. GOMES; G. M. CONCEIÇÃO, 92,93,94 (HABIT). 
2. Schnella glabra (Jacq.) Dugand Revista de la Academia Colombiana de Ciencias Exactas, Físicas y Naturales 4: 137. 1941.

Descrição: Liana de $2 \mathrm{~m}$ de altura, caule herbáceo, crescimento escandente, ramos castanhos puberulentos rígidos, estípulas diminutas a ausentes, folhas simples com 7,0 x 4,6 cm., folíolo simples bilobado em até 1/2 do limbo, ápice arredondado, pecíolo com 4,3 x 0,8 cm, alterna, nervura cuninervia, presença de ramos grampiformes, escandentes com aproximadamente $6 \mathrm{~cm} \times 0,3 \mathrm{~cm}$., Flor ausente. Frutos ausentes. Material Examinado: BRASIL. MARANHÃO: São João do Sóter, APP, 22/IV/2018, G. S. GOMES; G. M. CONCEIÇÃO, 88 (HABIT).

3. Bauhinia dubia G. Don Gen. Hist. 2: 463, 1832.

Descrição: Arbusto de $3 \mathrm{~m}$ de altura, caule lenhoso, crescimento simpodial, estipulas rudimentares presentes com $0,2 \times 0,1$ $\mathrm{cm}$, ramo glabro, pecíolo de $4 \times 0,2 \mathrm{~cm}$, folha simples de 7,5 × 4,3 cm, alterna, ausência de nectários, folíolos simples cordiforme a sagitado, sem corte no limbo, limbo com 3,4 x 3,6 cm, margem foliar inteira, ápice arredondado, face inferior puberulas a glabra. Flores ausentes. Fruto ausente. Material Examinado: BRASIL. MARANHÃO: Coelho Neto, Povoado Araim, 8/X/17, G. S. GOMES; G. M. CONCEIÇÃO 30, 31, 32, 37, 40 (HABIT).

4. $\quad$ Bauhinia ungulata L., Species Plantarum 1: 374. 1753.

Descrição: Subarbusto de 2,5 m de altura, crescimento simpodial, estípulas ovado-lanceoladas com $0,4 \times 0,2 \mathrm{~cm}$. Folhas bilobadas com 10 x $8,5 \mathrm{~cm}$., limbo fendido em mais de 1/2 da folha, folíolos simples, ovados a lanceolados, alterna, ausência de nectários, ápice obtuso, nervura marginal inconspícua, lobos concrescidos face superior glabra, face abaxial pubescente a tomentoso. Flor ausente. Fruto seco do tipo legume com 15 x $1 \mathrm{~cm}$. Material Examinado: BRASIL. MARANHÃO: Coelho Neto, Povoado Araim, 8/X/17, G. S. GOMES; G. M. CONCEIÇÃO 8, 29, 33, 38 (HABIT).

5. Bauhinia forficata Enum. Hort. Berol. Alt. 1: 404,1821.

Descrição: Subarbusto de $2 \mathrm{~m}$ de altura, caule acizentado cilíndrico, crescimento simpodial, estípulas ovado-lanceoladas com $1,3 \times 0,1 \mathrm{~cm}$, folhas bilobadas com $10 \times 10 \mathrm{~cm}$, folíolos simples, alterna, ausência de nectários, limbo partido, ápice obtuso, nervura marginal inconspícua, lobos concrescidos e arredondados, com face do folíolo adaxial e abaxial glabrascente pouco vilosa. Flor ausente, fruto seco do tipo legume com 8,0 x 0,9 cm. Material Examinado: BRASIL. MARANHÃO: Coelho Neto, Povoado Araim, 8/X/17, G. S. GOMES; G. M. CONCEIÇÃO 16 (HABIT).

6. $\quad$ Bauhinia cupulata Benth. Fl. Bras. 15 (2): 188, 1870.

Descrição: Arbusto de $2 \mathrm{~m}$ de altura, crescimento simpodial, caule cilíndricos cinza a esverdeado, estípulas obovadas com 0,1 x $0,1 \mathrm{~cm}$. Folhas simples, bilobadas, lobos foliares ovado-lanceolados, com ápice arredondado, com face adaxial pubescente $\mathrm{e}$ abaxial vilosa, lâmina com 13 x 9,1 cm. Flor ausente. Fruto ausente. Material Examinado: BRASIL. MARANHÃO: Coelho Neto, Povoado Araim, 8/X/17, G. S. GOMES; G. M. CONCEIÇÃO 28 (HABIT).

\section{Chave e descrição da subfamília Detarioideae}

1. Folhas bipinadas alterna dística, com 28-40 pares de folíolos, flores amarelas < $2 \mathrm{~cm}$ de compr...

1’. Folhas bifolioladas alterna não dística, flores brancas $>2 \mathrm{~cm}$ de compr...... 1. Tamarindus indica

'.

2. Hymenaea stigonocarpa

1. Hymenaea stigonocarpa Mart. Getreue Darstell. Gew. 11: sub pl. 13, 1830.

Descrição: Árvore de $15 \mathrm{~m}$ de altura, caule lenhoso, crescimento simpodial alongado, ramos glabros, folhas bifolioladas, alterna, forma do folíolo assimétrico ovada, sem indumento, folíolo com 11,0 x $5,0 \mathrm{~cm}$, pecíolo com $2,0 \mathrm{~cm}$, folha com $8,0 \mathrm{~cm}$, presença de pontuações no limbo foliar, margem inteira, ápice foliar emarginado, nervuras peninérveas a cuninervias. Flores brancas, botões florais clavados, sépalas externamente tomentosas. Fruto tipo legume bacóide seco odorífero, com aproximadamente 7,0 x $4 \mathrm{~cm}$. Material Examinado: BRASIL. MARANHÃO: Caxias, APA (Inhamul), 21/V/2018, G. S. GOMES; G. M. CONCEIÇÃO 56 (HABIT).

2. Tamarindus indica L. (Sp. Pl.)1: 34, 1753.

Descrição: Árvore de $12 \mathrm{~m}$ de compr., caule lenhoso, crescimento simpodial, copa alta, ramos amarronzados, estípulas rudimentares presentes com 0,2 cm de compr., folhas bipinadas, apresenta 28-40 pares de folíolos, alterna dística, folíolo oblongo com 1,0 x 0,3 cm, pecíolo com 3,0 cm de compr, margem foliar inteira, ápice foliar arredondado, nervura peninérvea. Flor ausente. Fruto do tipo baga, estruturas rugosas, marrom claro, ácido, sementes escuras. Material Examinado: BRASIL. MARANHÃO: Coelho Neto, Povoado Araim, 8/X/17; São João do Sóter, APP, 22/IV/2018, G. S. GOMES; G. M. CONCEIÇÃO 14, 99 (HABIT).

\section{Chave e descrição da subfamília Papilionoideae}

1. Liana trepadeira; fruto tipo legume com 3 sementes, margem do legume revoluta...................................... Dioclea bicolor

1'.Árvore, arbusto, subarbusto ou ervas herbáceas; fruto legume $>3$ sementes, sem margem revoluta

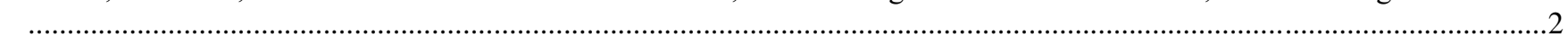


2. Árvore com crescimento secundário evidente

3. Árvore $>10 \mathrm{~m}$ altura, flores rosas com fruto sâmara.

2. Pterodon emarginatus

3'. Árvore $<10 \mathrm{~m}$ altura, flores lilás com fruto do tipo drupa.

3. Andira vermifuga

2'. Subarbusto ou erva apenas com crescimento primário evidente

4. Subarbustos eretos ou prostrados

5.Folhas trifolioladas, folíolos $>5 \mathrm{~cm}$ compr.

4. Cratylia argentea

5'. Folhas pinadas, folíolos $<5 \mathrm{~cm}$ compr.

6 . Folhas com $<20$ pares de folíolos

7. Fruto lomento castanho glabro

$\ldots 7$

7'. Fruto lomento verde piloso

5 Aeschynomene brasiliana

6'. Folhas $>20$ pares de folíolos

6. Aeschynomene martii

8. Estípulas caducas, frutos lomento avermelhados.

.8

8'. Estípulas persistentes, frutos lomento verde ou castanhos

7. Aeschynomene fluminenses

9. Estípulas triangulares, lomento com $<7$ artículos.

9'. Estípulas ovais, lomento com $>7$ artículos...

8. Aeschynomene histrix

9. Aeschynomene rudis

4'. Ervas trepadeiras ou herbáceas, decumbente, prostradas ou eretas .........................................................................10

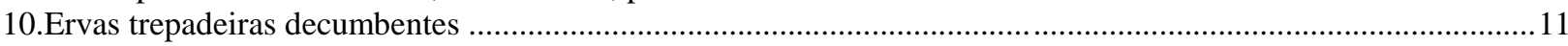

11.Folhas compostas com 8-15 pares de folíolos, inflorescência pseudo-racemosa

10. Abrus fruticulosus

11'. Folhas trifolioladas, inflorescência racemosa ou cimosa …………………………………………......12

12.Folíolo lanceolado a linear ou ovado longo .................................................................................... 13

13.Folíolo com $<5,0 \mathrm{~cm}$ compr. e $3 \mathrm{~cm}$ larg., flor papilionácea, pétalas lilás escura a roxeadas

11. Centrosema brasilianum

13'. Folíolo > 5,0 cm compr. e $1 \mathrm{~cm}$ larg., flor papilionácea pétalas brancas

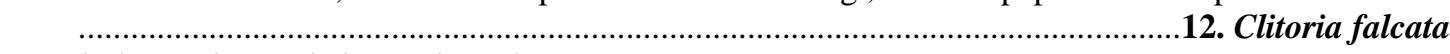

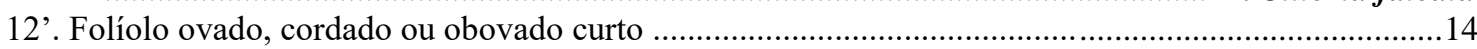

14.Folíolo ovado, sem lóbulos, flor papilionácea vermelha

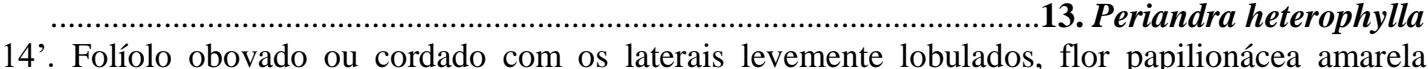

14. Folíolo obovado ou cordado com os laterais levemente lobulados, flor papilionácea amarela

15.Folíolo obovado com $4,5 \mathrm{~cm}$ compr. e $3 \mathrm{~cm}$ larg.................................14. Vigna unguiculata

15. Folíolos cordatos a sagitado, com $8 \mathrm{~cm}$ compr. e $4,3 \mathrm{~cm}$ larg.

15. Phaseolus vulgaris

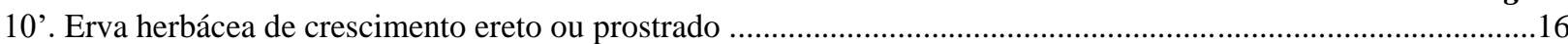

16.Folhas simples, fruto legume tipo cápsula ……………..................................................16. Crotalaria retusa

16'. Folhas compostas, fruto legume típico ou lomento …….........................................................................17

17.Fruto legume típico $>5 \mathrm{~cm}$ compr. ............................................................17. Macroptilium lathyroides

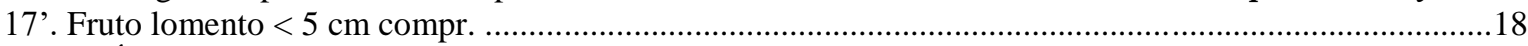

18. Ápice foliar arredondado, flor papilionáceas rosas a lilás...........................................................19

19. Folíolos elípticos, < $5 \mathrm{~cm}$ compr., estípulas concrescidas entre si

..............................................................................................................18. Desmodium incanum

19'. Folíolos elípticos, > $5 \mathrm{~cm}$ compr., estípulas livres, não concrescidas

19. Desmodium barbatum

18'. Ápice foliar acuminado ou agudo, flor papilionáceas amarelas .....................................................20

20. Folíolo linear com $1 \mathrm{~cm}$ compr., ápice foliar mucronado, lomento com $<6$ artículos

20. Zornia leptophylla

20'. Folíolo elíptico $>1 \mathrm{~cm}$ compr., ápice foliar agudo ou acuminado, lomento com 1 ou 2 artículos

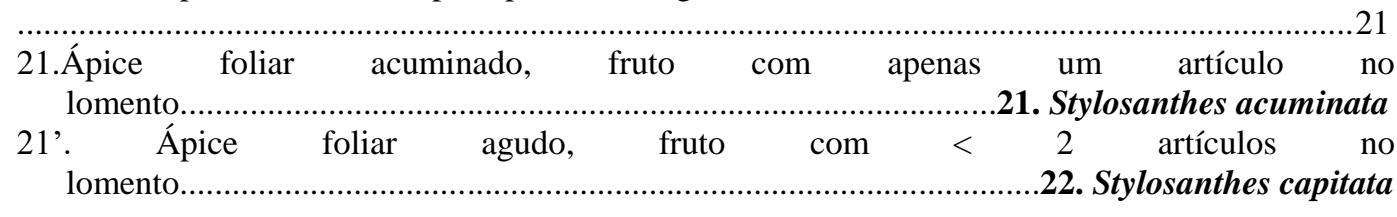

1. Dioclea bicolor Benth. (Comm. Legum. Gen.) 69, 1837.

Descrição: Liana de $2 \mathrm{~m}$ de altura, caule lenhoso, crescimento ereto, forma embira, estípulas lineares presentes com $0,6 \mathrm{~cm}$ de compr., folhas trifolioladas, alterna dística, folíolo oblongo lanceolado grande, com 8,0 x 5,0 cm, pecíolo com 4,6 x.13,1 cm, margem foliar inteira, ápice foliar arredondado, nervura peninérvea, pouco piloso, inflorescência racemosa, flores papilionáceas roxas, com base branca a amarela. Fruto seco tipo legume, com 4 x 1,6 cm de compr., margem revoluta, piloso, com 2-5 sementes. Material Examinado: BRASIL. MARANHÃO: São João do Sóter, APP, 22/IV/2018, G. S. GOMES; G. M. CONCEIÇÃO, 81 (HABIT). 
2. Pterodon emarginatus Vogel Linnaea 11: 384-385. 1837.

Descrição: Árvores de $15 \mathrm{~m}$ de altura, caule suberoso, estípulas ausentes. Folhas bipinadas, pecíolo com 2,0 x $2,5 \mathrm{~cm}$., tomentosos, raque com $18 \mathrm{~cm}$. Folíolos com 2,5 x 1,0 cm., concolores, cartáceos, alternos, elípticos, base obtusa a arredondada, ápice retuso, mucronado, pontuações translúcidas arredondas na lâmina dos folíolos, peciólulo $0,2 \mathrm{x} 0,2 \mathrm{~cm}$., tomentoso. Inflorescências paniculadas, axilares e terminais; Flores pediceladas, pedicelo 4-5 mm, tomentoso; cálice pentâmero, tomentos, com $1,0 \times 1,2 \mathrm{~cm}$, orbicular, rosas, internamente seríceo, obovadas, carena com $0,9 \times 0,3 \mathrm{~cm}$. Fruto sâmaras, com $5 \mathrm{~cm}$ de compr. Material Examinado: BRASIL. MARANHÃO: São João do Sóter, APP, 22/IV/2018, G. S. GOMES; G. M. CONCEIÇÃO, 91(HABIT).

3. Andira vermifuga Mart. ex Benth, Comm. Legum. Gen. 44-45. 1837.

Descrição: Árvores de 4,5 m de altura, caule rugoso, fendilhado, acinzentado. Ramos inermes, rugosos, estípulas lineares, caducas, pecíolo de 4,4 x 7,5 cm, glabro, raque 5,5-8,5 cm, glabra. Folhas compostas, folíolos 3,6 x 2,2 cm, discolores, coriáceos, subopostos, oblongos, base subcordada, ápice retuso a emarginado, glabros em ambas as faces, nervuras primárias e marginal proeminentes, peciólulo de 2-3 mm, pulverulento. Inflorescências paniculadas, terminais e axilares, brácteas não observadas. Flores pediceladas $4 \mathrm{~mm}$, pedicelo pulverulento, cálice campanulado, pentâmero, sépalas arroxeadas, pulverulentas, vexilo 1 × $1 \mathrm{~cm}$, rosa, orbicular, base unguiculada, ápice emarginado, glabro, com máculas lilás, alas 0.9 x 0,4 $\mathrm{cm}$, oblongas, base oblíqua a auriculada, glabras, carena 1,5 x 0,9 cm, oblonga, livre, glabra, ovário glabrescente. Fruto drupa ovóide, amarelada. Material Examinado: BRASIL. MARANHÃO: Caxias, APA (Inhamum), 21/V/2018, G. S. GOMES; G. M. CONCEIÇÃO 46, 47 (HABIT).

4. Cratylia argentea (Desv.) Kuntze Revisio Generum Plantarum 3(3): 58. 1898.

Descrição: Subarbusto de $2 \mathrm{~m}$ de altura, glabrescente, estípulas elíptico-lanceoladas e longas com $2,2 \mathrm{x} 0,1 \mathrm{~cm}$., folhas, trifolioladas, folíolos ovados e grandes com $9 \times 7,3 \mathrm{~cm}$., sendo outros maiores, margem inteira, face adaxial glabrescente, face abaxial tomentosa, pecíolo longo, inflorescência axilar, alterna, dística. Flor pedicelada, pequena, cálice campanulado, tubuloso, corola papilionácea, pétalas unguiculadas, lilás, Fruto do tipo legume com $12,3 \mathrm{x} 1 \mathrm{~cm}$. com valvas lignosas. Material Examinado: BRASIL. MARANHÃO: Coelho Neto, Povoado Araim, 8/X/17, G. S. GOMES; G. M. CONCEIÇÃO 7, 17 (HABIT).

5. Aeschynomene brasiliana (Poir.) DC. Prodr. 2: 322, 1825.

Descrição: Subarbusto de 1,2m de altura, Estípulas lanceoladas, não peltadas com $0,1 \mathrm{~cm}$ x 0,1 cm., folhas bipinadas com $4-14$ pares de folíolos, folíolos pequenos com $0,3 \mathrm{~cm}$ x $0,1 \mathrm{~cm}$. ápice redondo, margem inteira. Flor ausente. Frutos lomento com segmentos numerosos, interligados por istmo, com variação de tamanho de 4-6 x 0,3 cm de larg., margem superior inteira, castanho, glabro. Material Examinado: BRASIL. MARANHÃO: Coelho Neto, Povoado Araim, 8/X/17, G. S. GOMES; G. M. CONCEIÇÃO 4 (HABIT).

6. $\quad$ Aeschynomene martii Benth. Flora Brasiliensis 15(1A): 62, pl. 13. 1859.

Descrição: Arbusto de 1,5 m de altura, caule lignoso, cilíndrico, bem ramificada, ramos cilíndricos, Estípulas, estreitamente triangulares, não peltada, alterna, dística. Folha, imparipinadas, folíolos 15-17, alternos, oblongos, ápice obtuso, margem inteira, base assimétrica, face adaxial e abaxial glabro, Inflorescência axilar, pseudorracemo, pedúnculo curto. Botão obovado. Flor ausente. Fruto lomento, bi-triarticulado, plano, verde, suavemente piloso. Material Examinado: BRASIL. MARANHÃO: Caxias, APA (Inhamum), 21/V/2018, G. S. GOMES; G. M. CONCEIÇÃO 45 (HABIT).

7. Aeschynomene fluminensis Vell. Fl. Flumin. 310, 1825.

Descrição: Arbusto de $1 \mathrm{~m}$ de altura, ramos glabrescentes a pubescentes, castanhos, hidrófila. Estípulas caducas, peltadas, com 0,4 x 0,9 cm., lanceoladas, ápice acuminado, base oblíqua, margem inteira a serrilhada, ciliada. Folhas com 6-18 pares de folíolos de 0,5 x 1,3 cm de larg, oblanceolados, glabrescentes, ápice agudo a obtuso-mucronulado, base oblíqua, margem inteira, nervura peninérveas, margem inteira a serrulada, ciliada. Bractéolas de 0,2 x $0,3 \mathrm{~cm}$ compr. Flor ausente. Fruto Lomento com $5 \mathrm{~cm}$ compr., coloração avermelhada, artículos 3-7, com 0,4 x 0,4 cm. Material Examinado: BRASIL. MARANHÃO: Caxias, APA (Inhamum), 21/V/2018, G. S. GOMES; G. M. CONCEIÇÃO 42, 43 (HABIT).

8. $\quad$ Aeschynomene histrix Poir. Encycl., Suppl. 4(1): 77-78, 1816.

Descrição: Erva de $45 \mathrm{~cm}$ de altura, crescimento ereto decumbente, estipulas triangulares presentes, não peltada, com $0,3 \mathrm{x}$ 0,1 cm de larg. apresenta-se na base do pecíolo, estriada. Folhas bipinadas com 20-30 pares de folíolos, alterna, pecíolo de 4 x 0,4 cm. Folíolos de 0,7 x 0,2 cm., oposto, oblongos, margem foliar inteira, ápice acuminado, indumento piloso, com tricomas esbranquiçados. Flor ausente. Fruto seco, legume lomento com istmo, com ca. 3cm compr. apresenta de 4-7 artículos indumentado, verde a marrom claro. Material Examinado: BRASIL. MARANHÃO: São João do Sóter, APP, 22/IV/2018; Caxias, APA (Inhamum) G. S. GOMES; G. M. CONCEIÇÃO 44,73,74,75 (HABIT).

9. Aeschynomene rudis Benth Plantas Hartwegianas imprimis Mexicanas 116.1843.

Descrição: Subarbusto de 1,5 m de altura, com caule lignoso, coloração verde escura, estípulas ovais persistentes, com $0,1 \mathrm{x}$ 0,1 cm., folhas, bipinadas, com 30-50 pares de folíolos, folíolos com $0,3 \times 0,1 \mathrm{~cm}$. ápice redondo, margem inteira. Flor ausente. Fruto do tipo lomento, com 3-12 artículos, curvado, com segmentos fusiformes, variação de tamanho que vai de 3 x 
0,3 cm., margem superior inteira, castanhos enegrecidos. Material Examinado: BRASIL. MARANHÃO: Coelho Neto, Povoado Araim, 8/X/17, G. S. GOMES; G. M. CONCEIÇÃO 19 (HABIT).

10. $\quad$ Abrus fruticulosus Wight \& Arn. (Prod. Fl. Ind. Orient.) 1: 236, 1834.

Descrição: Erva de $1 \mathrm{~m}$ de compr., com caule herbáceo, indumento no ramo presente. Estípulas lineares, diminutas na base do peciólulo, pecíolo com 3,5 × $2 \mathrm{~cm}$, folhas compostas com 8-15 pares de folíolos, bipinadas com 2,3 x 0,9 cm de larg. folíolos obovados, lineares; indumento no folíolo, margem lisa, nervura peninérvea, ápice arredondado, limbo simétrico. Inflorescência pseudo-racemosa, flores imaturas. Fruto ausente. Material Examinado: BRASIL. MARANHÃO: Coelho Neto, Povoado Araim, 8/X/17, G. S. GOMES; G. M. CONCEIÇÃO 35 (HABIT).

\section{Centrosema brasilianum (L.) Benth Comm. Legum. Gen. 54,1837.}

Descrição: Erva de 1,5m de altura, apresenta estípulas do tipo ócrea triangulares na base do pecíolo de $0,3 \times 0,2 \mathrm{~cm}$., folhas trifolioladas, com um par oposto na base e um alongado pela ráquis, folha com $7 \mathrm{~cm}$ de compr., alterna dística, folíolos com 4,8 x $3 \mathrm{~cm}$ de larg. lanceolados a linear, margem lisa, ápice agudo, nervura peninérvea, tricomas pouco evidente. Flor racemosa, papilionácea, pétalas lilás, pétalas unguiculadas, estandarte calcarado com inflorescência axilar, heteroclamídea, diclamídea, dialistêmones, alas e quilhas unidas na base do estandarte completa, fruto legume típico 7,0 x 0,4 cm, linear. Material Examinado: BRASIL. MARANHÃO: Coelho Neto, Povoado Araim, 8/X/17; Caxias, APA (Inhamun), 21/V/2018, G. S. GOMES; G. M. CONCEIÇÃO 5, 39, 48, 49 (HABIT).

\section{Clitoria falcata Lam. Encycl. 2(1): 51, 1786}

Descrição: Erva de 1,3 m de altura; ramos estriados, inermes, hirsutos, estípulas 0,6 x 0,3 cm., persistentes, ovaladas, ápice agudo, base truncada, margem ciliada, superfície pubescente, nervuras conspícuas adaxialmente e abaxialmente, pecíolo com 4 $\mathrm{cm}$ comp.; raque foliar $0,1 \times 0,2 \mathrm{~cm}$. Folhas trifolioladas com folíolos $8 \times 1,5 \mathrm{~cm}$., lanceolados a ovalados, ápice cuneado. Inflorescência em racemo, axilar, pedúnculo $0,9 \times 0,8 \mathrm{~cm}$. Flor racemosa branca com pétalas da quilha 2,5. x 0,5 cm, ovaladas a elípticas, margem inteira. Fruto ausente. Material Examinado: BRASIL. MARANHÃO: São João do Sóter, APP, 22/IV/2018, G. S. GOMES; G. M. CONCEIÇÃO, 77, 78 (HABIT).

\section{Periandra heterophylla Benth. (Comm. Legum. Gen.) 57,1837.}

Descrição: Erva trepadeira de 1,20 m de altura, caule tipo haste herbáceo, crescimento ereto decumbente, presença de estípulas lineares com $0,4 \mathrm{~cm}$, ausência de nectários, folhas trifolioladas, alterna, folíolo ovado sem lóbulos, com $10 \times 6,1 \mathrm{~cm}$., pecíolo com $5,0 \mathrm{~cm}$, folha com $c a .8,0 \mathrm{~cm}$, margem inteira, ápice foliar mucronado, nervura peninérvea marcada, folíolo simétrico, presença de tricomas nos folíolos e nos aramos, pilosidade homogênea, Inflorescência cimosa com $0,8 \mathrm{~cm}$ de compr., Flor racemosa em botões vermelhos. Fruto ausente. Material Examinado: BRASIL. MARANHÃO: São João do Sóter, APP, 22/IV/2018, G. S. GOMES; G. M. CONCEIÇÃO, 87 (HABIT).

\section{Vigna unguiculata (L.) Walp. Repert. Bot. Syst. 1 (5): 779,1843.}

Descrição: Erva de $30 \mathrm{~cm}$ de comprimento, crescimento ereto, caule herbáceo, ramos esverdeados, estípulas triangulares de $0,2 \times 1 \mathrm{~cm}$. folhas trifolioladas, alternas, levemente lobuladas, estrutura adaxial com nervura peninérvea secundária marcadas nos folíolos, folíolo obovado com 4,5 × $3 \mathrm{~cm}$., ápice foliar agudo, pecíolo com 0,4 x 0,1 cm., margem inteira, simétrica, presença de tricomas nos folíolos, Inflorescência racemosa, axial, flor amarela, zigomorfa, aclamídea, papilionácea. Fruto seco do tipo legume longo com 3 x 0,2 cm. com tricomas. Material Examinado: BRASIL. MARANHÃO: Coelho Neto, Povoado Araim, 8/X/17, G. S. GOMES; G. M. CONCEIÇÃO 1 (HABIT).

\section{Phaseolus vulgaris L. Sp. Pl. 2: 723, 1753.}

Descrição: Erva de $20 \mathrm{~cm}$ de altura, crescimento ereto decumbente, ramos esverdeados, estípulas ausentes, folhas trifolioladas, alternas, folíolos cordatos a sagitado, com lóbulos nos folíolos, com 8 × 4,3 cm. pecíolo com $0,2 \times 0,1 \mathrm{~cm}$ de compr., folhas com 8,2 × 3,6 cm., margem inteira ondulada, nervura peninérvea, ápice foliar agudo, simétrico, pulvino reduzido, raquer truncada. Flor em forma racemos com botões imaturos amarelos. Fruto ausente. Material Examinado: BRASIL. MARANHÃO: São João do Sóter, APP, 22/IV/2018, G. S. GOMES; G. M. CONCEIÇÃO, 89 (HABIT).

\section{Crotalaria retusa L. Sp. Pl. 2: 715, 1753.}

Descrição: Erva de $50 \mathrm{~cm}$ de altura, crescimento ereto, estípulas lineares presentes com $0,4 \times 0,2 \mathrm{~cm}$, nectários ausentes, folhas simples, alterna, folíolos obovados, com 4,2 x $1,5 \mathrm{~cm}$, pecíolo com $0,3 \mathrm{~cm}$, folha com aproximadamente $4,6 \times 4 \mathrm{~cm}$., margem foliar inteira, ápice emarginado, nervura peninérvea. Inflorescência cimosa, flor amarela, corola com pétalas unguiculadas, estandarte estriado na base. Fruto seco, cápsula, com aproximadamente 3,0 x 0,8 cm. com terminal do legume agudo. Material Examinado: BRASIL. MARANHÃO: Coelho Neto, Povoado Araim, 8/X/17; São João do Sóter, APA, 22/IV/2018, G. S. GOMES; G. M. CONCEIÇÃO 3, 6, 34, 36, 79, 80 (HABIT).

\section{Macroptilium lathyroides (L.) Urb. Symb. Antill. 9 (4): 457, 1928.}

Descrição: Erva de $30 \mathrm{~cm}$ de altura, ramos esverdeados, estípulas triangulares diminutas presentes com $0,5 \times 0,2 \mathrm{~cm}$. , presença de nectário arredondado no pecíolo, folhas trifolioladas, alterna dística, folíolo lanceolado a linear, com 4,0 x 2,6 cm, pecíolo com $5 \mathrm{~cm}$, folha com 7,0 cm de comprimento, margem foliar inteira, ápice foliar agudo, simétrico, ápice foliar obtuso a 
codiforme, presença de tricomas dispersos. Flor com corola assimétrica, alas grandes, quilha cocleada. Fruto seco tipo legume longo, com ca de 5,6 cm, indeiscente. Material Examinado: BRASIL. MARANHÃO: Coelho Neto, Povoado Araim, 8/X/17, G. S. GOMES; G. M. CONCEIÇÃO 2, 18 (HABIT).

\section{Desmodium incanum (Sw.) DC. Prodr. 2: 332, 1825}

Descrição: Erva de $50 \mathrm{~cm}$ de altura, crescimento ereto decumbente, estípulas triangulares concrescidas entre si, com 0,6 x 0,2 $\mathrm{cm}$ na base do pecíolo, folhas trifolioladas, alterna dística, folíolos elípticos, com 2,4 x 1,1 cm, pecíolo com $1,5 \mathrm{~cm}$, folha com aproximadamente 4,0 cm, margem foliar inteira, ápice arredondado, simétrica, nervura peninérvea, presença de tricomas, pilosidade mediana. Inflorescência racemosa. Flor papilionáceas, rosas, diminutas. Fruto seco tipo lomento, com 1,1 cm de compr., possuindo de 3-5 artículos com tricomas aderentes. Material Examinado: BRASIL. MARANHÃO: Caxias, APA, (Inhamum), 21/V/2018, G. S. GOMES; G. M. CONCEIÇÃO 55 (HABIT).

19. Desmodium barbatum (L.) Benth. \& Oerst. Vidensk. Meddel Dansk Naturhist. Foren Kjøbenhavn 1853 (1-2): 18, 1853.

Descrição: Erva de $80 \mathrm{~cm}$ de altura, caule lenhoso, crescimento ereto, estípulas triangulares livres, com $0,6 \mathrm{~cm}$ de compr., folhas trifolioladas, alterna dística, folíolos elípticos simétrico, com 5 x 3,6 cm, pecíolo com 1,5 cm de comprimento, folha com aproximadamente 4,0 cm., margem foliar inteira, ápice arredondado, pilosidade com tricomas esbranquiçados, nervura peninérvea. Inflorescência racemosa. Flor papilionáceas lilás a roxas diminutas. Fruto seco tipo lomento, com 3,3 x 0,8 cm., possui de 3-6 artículos indumentado, aderente. Material Examinado: BRASIL. MARANHÃO: Caxias, APA (Inhmaul), 21/V/2018, G. S. GOMES; G. M. CONCEIÇÃO 52, 53, 54 (HABIT).

20. Zornia leptophylla (Benth.) Pittier (Benth.) Pittier, Boletín de la Sociedad Venezolana de Ciencias Naturales 6(44): 196. 1940.

Descrição: Erva de $30 \mathrm{~cm}$ de altura., ramo muito difuso, cilíndrico, inerme com tricoma glandular. Estípula de $0,1 \mathrm{x} 0,1 \mathrm{~cm}$, caduca, alterna, dística. Folha bifoliolada, folíolo linear 1,0 x 0,5 cm, ápice mucronado, margem inteira, base cuneada, tricoma glandular em ambas faces, pecíolo com inflorescência axilar, espiciforme, tricoma glandular presente. Flor séssil, monoica, pequena, cálice campanulado, corola papilionácea, unguiculada, amarela, estandarte orbicular, ala livre, obovada. Fruto lomento, moniliforme, 2-6 segmentos, epicarpo faveolado, aculeado. Material Examinado: BRASIL. MARANHÃO: Caxias, APA (Inhamum), 21/V/2018, G. S. GOMES; G. M. CONCEIÇÃO 72 (HABIT).

21. Stylosanthes acuminata M. B. Ferreira \& Souza Costa, Soc. Bot. Brasil Anais. 28 Congr. Nac. Bot.: 80.1977.

Descrição: Erva de $50 \mathrm{~cm}$ de altura, ereto, ramos vilosos ou tomentosos, estípula externa, oblonga, obovada, ápice subulado com 0,3 x 0,2 cm., pecíolo tomentoso. Folhas trifolioladas, folíolo elíptico, 3,0 x 1,5cm de larg., ápice acuminado. Inflorescência oblonga, corola amarela, estandarte obovado, largo-obovado ou obcordado, ápice obcordado asas obovados, pétalas da quilha elípticas, ligeiramente falciformes. Fruto lomento com 1 artículo, oblongo, glabro, 2,5 x 2,5 cm de larg. Material Examinado: BRASIL. MARANHÃO: Caxias, APP (Inhamum), 21/V/2018, G. S. GOMES; G. M. CONCEIÇÃO $67,68,69,70,71$ (HABIT).

\section{Stylosanthes capitata Vogel Linnaea 12: 70, 1838.}

Descrição: Erva de $30 \mathrm{~cm}$ de altura, caule herbáceo, crescimento ereto decumbente, ramos esverdeados, com estípulas triangulares de $0,5 \mathrm{~cm}$ de comp., na base do pecíolo, folhas trifolioladas, alterna dística, folíolo elíptico, com 1,9 x 0,6 cm., pecíolo com $0,5 \times 0,2 \mathrm{~cm}$., folha com aproximadamente $2,5 \mathrm{~cm}$, margem inteira, ápice foliar agudo, nervura peninérvea, presença de tricomas glandulares em todo ramos, pilosidade homogênea, folíolos simétricos. Inflorescência cimosa com 4,5 cm de compr. Flores diclamídea, heteroclamídea, gamossépalas com 0,4 cm de comp., gamopétalas com simetria zigomorfa, amarelas papilionáceas, pilosas, estandarte estriado marcado com coloração vermelha. Fruto ausente. Material Examinado: BRASIL. MARANHÃO: Caxias, APP (Inhamum), 21/V/2018, G. S. GOMES; G. M. CONCEIÇÃO 46, 66 (HABIT)

\section{CONCLUSÃO}

O estudo taxonômico da família Leguminosae preenche lacunas no conhecimento da diversidade de espécies botânicas no Cerrado do Maranhão, visto que a família é um componente essencial do Cerrado maranhense e brasileiro. O trabalho fornece a maior lista de espécies de Leguminosae para o Cerrado do Maranhão, mostrando a importância e o potencial florístico e taxonômico da flora do estado, servindo de base e estímulos para pesquisas desse cunho.

\section{AGRADECIMENTOS}

Ao Conselho Nacional de Desenvolvimento Científico e Tecnológico (CNPq), pela concessão de Bolsa de Iniciação Científica (IC), a Universidade Estadual do Maranhão
(UEMA), Centro de Estudos Superiores de Caxias/CESC e ao Laboratório de Biologia Vegetal/LABIVE, pelo apoio e infraestrutura fornecida durante a realização da pesquisa.

\section{REFERÊNCIAS}

BARNEBY, R. C. Sensitivae Censitae. A description of the genus Mimosa L. (Mimosaceae) in the New World. Memoirs of the New York Botanical Garden, v.65, 1991. 835p.

BARroso, G. M., MORIM, M. P., PEIXOTO, A. L.; ICHASSO, C. L. F. Frutos e sementes: morfologia aplicada à sistemática de dicotiledôneas. Imprensa Universitária, Viçosa. 1999. 443p. 
BFG. Growing knowledge: an overview of seed plant diversity in Brazil. Rodriguésia. v. 66, p. 1085-1113, 2015. http://dx.doi.org/10.1590/2175-7860201566411

DRYFLOR. Plant diversity patters in neotropical dry forests and their conservation implications. Science. v. 353. p. $1383-$ 1387, 2016. 10.1126/ science.aaf5080

FLORA DO BRASIL. Lista de Espécies da Flora do Brasil. Jardim Botânico do Rio de Janeiro. Disponível em: <http://floradobrasil.jbrj.gov.br/>. Acessada em: 22/01/2018.

GALINKIN, M.; DIAS, A.; LATRUBESSE, E. M.; SCARDUA, F. P.; MENDONÇA, A. F.; ARRUDA, M. B. Projeto Corredor Ecológico Araguaia - Bananal. In: Arruda, M. B.; SÁ, L. F. S. N. (Org.) Corredores Ecológicos - Uma abordagem integradora de ecossistemas no Brasil. Brasília: Ed. IBAMA. p. 81-132, 2004.

GOMES, G. S.; SILVA, G. S.; CONCEIÇÃO, G. M. Florística Taxonomia do Clado Mimosoide (Fabaceae, Caesalpinioideae) no Município de São João do Sóter, Maranhão, Brasil. Agrarian academy, v.4, n.8, p.153-163, 2017.

http://dx.doi.org/10.18677/Agrarian_Academy_2017b16

GOMES, G. S.; VELOZO, C. O.; SILVA, A. M.; SILVA, G. S.; CONCEIÇÃO, G. M. Fabaceae Lind. of the Environmental Protection Area of the Middle Buriti, Caxias, Maranhão, Brazil. Agrarian academy, v.3, n.06, p. 15, 2016. http://dx.doi.org/10.18677/Agrarian_Academy_2016b6

IMESC. Perfil do Maranhão 2006/2007, São Luís: Instituto Maranhense de Estudos Socioeconômicos e Cartográficos. version 1, p. 197. 2008.

IBGE. Instituto Brasileiro de Geografia e Estatística. Perfil dos estados (2014). Online. Disponível em: <http://www.ibge.gov.br/estadosat/perfil.php?sigla=ma> Acesso em: 15/01/2019.

IBGE. Manual Técnico da Vegetação Brasileira. Ministério do Planejamento, Orçamento e Gestão. Instituto Brasileiro de Geografia e Estatística - IBGE. Rio de Janeiro, p. 271, 2012.

JORDÃO, L. S. B.; MORIM P. M.; BAUMGRATZ, F. A. Toward a Census of Mimosa (Leguminosae) in the Atlantic Domain, Southeastern Brazil. Systematic Botany. v. 43. n.1. p. 162- 197, 2018 https://doi.org/10.1600/036364418X696905

JUDD, W. S.; CAMPBELl, C. S.; KELlOGG, E. A.; STEVENS, P. F. Plant Systematics: a phylogenetic approach. Sunderland - Massachusetts, Sinauer Associates. p. 464. 1999.

LAVIN, M.; SCHRIRE, B. P.; LEWIS. G. P.; PENNINGTON, R. T.; DELGADO-SALINAS, A.; THULIN, M.; HUGHES, C. E.; MATOS, A. B.; WOJCIECHOWSKI, M. F. Metacommunity process rather than continental tectonic history better explains geographically structured phylogenies in legumes. Philosophical Transactions of The
Royal Society B: Biological Sciences, v.359. p.14, 2004. https://doi.org/10.1098/rstb.2004.1536.

LEWIS, G. P.; SCHRIRE, B. D.; MACKINDER, B. A.; LOCK, J. M. Legumes of the World. Royal Botanic Gardens, Kew. p. 577, 2005.

LEWIS, G. P. Legumes of Bahia. Royal Botanic Gardens, Kew. p. 369, 1987.

LIMA, G. P.; NETO, C. A. A. P.; AMARAL, Y. T.; SIQUEIRA, G. M. Biogeographical Characterization of the Maranhense Eastern Mesoregion (BRAZIL). Journal of Geospatial Modelling, v.1, n.1, p. 1-12, 2016. http://dx.doi.org/10.22615/jgm-1.1-5809.

LPWG. Legume Phylogeny Working Group. A new subfamily classification of the Leguminosae based on a taxonomically comprehensive phylogeny. Taxon. v. 66, n.1, p. 44- 77, 2017. http://dx.doi.org/10.12705/661.3.

MARANHÃO. Plano de Ação Para Prevenção e Controle do Desmatamento e das Queimadas no Estado do Maranhão. Governo do Estado do Maranhão. Secretaria de Estado do Meio Ambiente e Recursos Naturais. 2011. 110p.

MENDONÇA, R. C.; FELFILI, J. M.; WALTER, B. M. T.; SILVA JÚNIOR, M. C.; REZENDE, A. V.; FILGUEIRAS, T. S.; NOGUEIRA, P. E.; FAGG, C. W. Flora vascular do Cerrado: Chechlist com 12.356 espécies. In: SANO, S.M.; ALMEIDA, S.P.; RIBEIRO, J.F. Cerrado: ecologia e flora. Embrapa-CPAC, Planaltina, p.417-1279, 2008.

MORI, S. A.; SILVA, L. A. M.; LISBOA, G.; CORADIN, L. Manual de Manejo de Herbário Fanerogâmico. 2a ed. Ilhéus, Centro de Pesquisas do Cacau. 1989. 104p.

OLIVEIRA-FILHO, A. T.; RATTER, J. A. A study of the origin of Central Brazilian forests by the analysis of plant species distribution patterns. Edinburg Journal Botany. v. 52. p. 141-194, 1995. https://doi.org/10.1017/S0960428600000949.

QUEIROZ, L. P. Leguminosas da Caatinga. Universidade Estadual de Feira de Santana. 2009. 443 p.

RATTER, J. A.; BRIDGEWATER, S.; RIBEIRO, J. F. Analysis of the floristic composition of the Brazilian Cerrado vegetation III: comparison of woody vegetation of 376 areas. Edinburgh Journal Botany. v. 60, n. 1, p. 57-109, 2003. http://dx.doi.org/10.10M/S0960428603000064.

RADFORD, A. E.; DICKISON, W. C.; MASSEY, J. R.; BELL, C. R. Vascular plant systematics. Harper \& Row, New York. 1974. 891p.

RIBEIRO, J. F.; SANO, S. M.; MACÊDO, J.; SILVA, J. A. Os principais tipos fitofisionômicos da região dos Cerrados. Planaltina, DF: Embrapa-CPAC, 1983. 28p.

SIMON, M. F.; GRETHER, R.; QUEIROZ, L. P.; SARKINEN, T. E.; DUTRA, V. F.; HUGHES, C. E. The evolutionary history of Mimosa (Leguminosae): Toward 
phylogeny of the sensitive plant. American Journal of Botany. v. 98, p. 2011. http://dx.doi.org/10.3732/ajb.1000520.

SCHMIDT-SILVEIRA, F.; MIOTTO, S. T. S. A família Fabaceae no Morro Santana, Porto Alegre, Rio Grande do Sul, Brasil: aspectos taxonômicos e ecológicos. Revista Brasileira de Biociências, v. 11, n. 1. p. 93-114, 2013.

SILVA, G. S. Fabaceae Lind. da Área de Proteção Ambiental Municipal do Inhamum, Caxias, Maranhão, Brasil. Monografia (Graduação em Ciências Biológicas) Universidade Estadual do Maranhão, Centro de Estudos Superiores de Caxias. 132p. 2016.

SPINELLI-ARAUJO, L.; BAYMA-SILVA, G.; TORRESAN, F. E.; VICTORIA, D.; VICENTE, L. E. BOLFE. E. L.; MANZATTO, C. Conservação da Biodiversidade do Estado do Maranhão: Cenário Atual em dados Geoespaciais. Embrapa Meio Ambiente Jaguariúna. 2016. 28p.

SPRENT J. I.; ARDLEY J.; JAMES E. K. Biogeography of nodulated legumes and their nitrogen-fixing symbionts. New Phytol. v.215, p.40-56, 2017. http://dx.doi.org/10.1111/nph.14474.

SOUZA, V. C.; LORENZI, H. Botânica Sistemática: guia ilustrado para identificação das famílias de fanerógamas nativas e exóticas no Brasil, baseado em APG III. $3^{\mathrm{a}}$ ed. Instituto Plantarum, Nova Odessa, São Paulo. 2012. 768p.

THE PLANT LIST. The plant list: a working list of all plant species. 2018. Disponível em: <www.theplantlist.org.> Acesso em: 15/01/2019.

TRÓPICOS. Missouri Botanical Garden. 2019. Disponível em: <www.tropicos.org.> Acesso em: 15/01/2019.

YAHARA, T.; FIROUZEH, J.; ONODA, Y.; QUEIROZ, L. P.; FAITH, D. P.; PRADO, D. E.; AKASAKA, M.; KADOYA, T, ISHIHAMA, F.; DAVIES, S. J. W.; YI, T. K. M.; BIN. C.; DEDY, D. R.; PENNINGTON, T.; TUDA, M.; SHIMADA, M.; ITO, M.; EGAN, A. N.; BUERKI, S.; RAES, N.; KAJITA, T.; VATANPARAST, M.; MIMURA, M.; TACHIDA, H.; IWASA, Y.; SMITH, G. F.; VICTOR, J. E.; NKONKI, T. Global legume diversity assessment: Concepts, key indicators, and strategies. Taxon. v. 62, p. 249266, 2013. http://dx.doi.org/10.12705/622.12. 